\title{
Exploring the Role of Merchant Banker as Capital Market Intermediary: With Special Reference to Role Played Under Stock Market
}

\author{
Subhajit Chakraborty
}

\begin{abstract}
For smooth and effective governance of corporate organizations and to achieve a sustainable development in the corporate fraternity, organizations require finance both for financing the fixed capital as well as for working capital. Finance is such an important aspect of business that enterprises cannot sustain without its interference and as such right from its incorporation till it's winding up finance occupies a pivotal position. It is not only for the small and big enterprises which requires finance but also the entire economic structure of the country keeps reliance on it. As corporate sector contributes towards Indian economy about $53 \%$ of Gross Domestic Product, the role of security market under the cloak of Security Exchange Board of India plays an important role in contributing to the Indian Economy. Security market also known as the stock market is a platform where a company can raise its fund or share-capital through the means of various kinds of marketable and financial instruments carrying voting rights, interest and payment of dividend both at domestic and international level. For a sustainable corporate governance, a compliance framework has to be established which will help and support the risk management system during identifying the sources of corporate funding and the pools of fund both from domestic capital market and international markets. Corporates should first create an established framework which will help them to evaluate and assess their financial requirement to the extent of managing funds from various sources. It is true that a company issues securities to the investors through the mechanism of initial public offering and further public offering in primary market and in furtherance such securities are additionally traded in secondary market through the platform of recognized stock exchange which makes it crystal clear that there is no direct congruence or connection between the issuer company and the security holders. In this gap the role played by the intermediaries are pertinent for the operations relating to issuance and trading of securities and as such merchant banker is one of the key intermediary in capital market appointed by the issuer company for public issue management. The paper will focus on the role played by the merchant banker in primary market. It will also attempt to define how the merchant banker functions with due regard to public issue management, credit rating of shares and how it complies with the changing laws and regulations for an effective management of corporate transactions.
\end{abstract}

Keywords: promoting, finance, intermediary, capital market, merchant banker

\section{INTRODUCTION}

$\mathrm{T}$ he role of Intermediaries in capital market has added a wide-ranging significance in promoting a brand image for corporations and its share-capital and hence contributing towards smooth functioning of corporate business transactions between the Issuer Company and investors or

Revised Manuscript Received on June 12, 2020

*Corresponding Author

Subhajit Chakraborty*, Subhajit Chakraborty, Assistant Professor of Law, Adamas University

(C) The Authors. Published by Blue Eyes Intelligence Engineering and Sciences Publication (BEIESP). This is an open access article under the CC BY-NC-ND license (http://creativecommons.org/licenses/by-nc-nd/4.0/) traders in both primary market and secondary market. Among other intermediaries of capital markets like Portfolio managers, Stock Exchange, Registrar to an Issue, Banker to an issue, Brokers etc. merchant banker plays a vital role in the stock market by managing public issue both Initial Public offer and Further Public offer and hence they are called in various terminologies like investment bankers, issue managers, lead managers supporting the Issuer company to get indulge in the security market with initial public issue. In order to raise fund or adding more to the share-capital, the merchant banker helps the issuer company to evaluate and assess the capital needs of the company and therefore it lays down the structure of financial instruments through which the organization can pool funds from different sources. The structure of financial securities drawn by the merchant banker to boost its capital needs includes equity shares, preferential shares, shares with differential voting rights, debentures, bonds etc. and before the issuance of such financial securities through a recognized stock exchange the investment managers assess and pre-determines the debt-equity-ratio of the company. Apart from facilitating the Issuer company to assess the security market, merchant bankers helps the company in fixation of the price of financial instruments and operates the entire public issue process of securities till its allotment. It manages the securities which are to be issued and listed under recognized stock exchange. Merchant bankers also indulges other intermediaries like broker, credit rating agencies, underwriters etc. for an effective public issue management and all such intermediaries are authenticated which adds value to corporate business transactions. Intermediaries including the merchant banker who are the main players in corporate finance are required to be registered under Security Exchange Board of India. The entire process of security trade mechanism invokes the plenary role of all the registered intermediaries including the role played by the merchant banker in making financial decisions for raising the share capital value of the company to the extent of maximization of shareholders wealth.

\section{II.LITERATURE REVIEW}

The paper titled "Role of Intermediaries in Security Markets" throws light on the significant role played by the capital market intermediary in security trading mechanism and other multifaceted operations (Priyanshi Singh, 2015). The paper named "Understanding the basics of Securities Market" discuss about the important players under the stock market. It also deals with some pertinent questions involving primary and secondary market (NISM Certification).

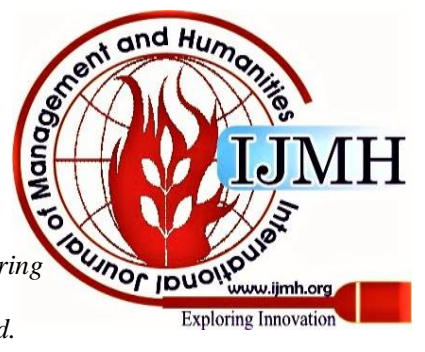


The Study clarifies the role and services played by the merchant bankers within the periphery of capital market also how it helps in reinforcing economic development of the country (Business Jargon).

The write up published in Federal Bank official website about how they are dealing with the stock market in connection to merchant banker services. It is also providing the services offered by the merchant banker services in IPO AND FPO. (Federal Bank: Merchant Banker Services).

The report was drawn from the website of CRISIL in regarding its achievements as rating the companies indulged in stock market also how the CRISIL dealt with merchant bankers in public issue management.(CRISIL: Report of 2016-17)

The blog was posted in the official page of Kalyan City Life which extensively dealt with the funtions of merchant bankers as capital market intermediary and how it helps in public issue management, corporate restructuring, money market operations etc. (Gaurav Akrani, 2011)

The study of merchant banker and its diversified roles played under Capital market as contained in the official Website of Axis Bank Merchant Banker Services.(Axis Bank: Merchant Banker Services).

The study provides the role, function of merchant bankers and how they are governed by regulations. It also attempts to discuss the code of conduct for the registered merchant bankers and the diversified played as capital market intermediary (Shambhavi Kumar, 2016)

The report provided a key insight of success of top five merchant bankers in India and across the world. The merchant bankers were ranked as per Initial public offering and Equity capital market (Business Standard. 2016)

\section{OBJECTIVES OF THE STUDY}

A. To identify and explore the role of Merchant Bankers in Security trading Mechanism.

B. To understand the contributions made by the merchant bankers in effective corporate finance and governance.

C. To discuss the diversified roles and services played by merchant bankers.

D. To identify the risk and challenges confronted by Merchant bankers.

\section{RESEARCH METHODOLOGY}

The present study is descriptive and analytical in nature and is conducted on the basis of secondary sources and materials. The research is conducted based on the study of relevant articles and current reports of merchant bankers engaged in stock market in India. The result of the paper was a culmination of articles, newspaper and reports published in business and economic times about exploring the role of merchant banker as capital market intermediary and the risks and challenges which they may face in corporate transactions. The researcher has made an extensive review of the role played by the leading merchant bankers like Axis Bank, ICICI Bank in the managing public issue and smooth governance of the company.

\section{V.EXPLORING THE ROLE OF MERCHANT BANKER AS CAPITAL MARKET INTERMEDIARY}

Merchant banking is indisputably a skill-oriented service provided by a number of financial institutions that ensures growth and opulence in the corporate sector which is ultimately manifested in the overall economic development of the country. Merchant bankers are expected to discharge several functions like issue management, underwriting, portfolio management, loan syndication, consultancy, counseling and a host of other activities. Merchant banking is an effective amalgamation of banking and consultancy services. It provides consultancy to its clients, for financial, marketing, managerial and legal matters. Consultancy encompasses occupations as providing advice, guidance and service for a fee. It enables a businessman to start a business, to raise finance, to expand, modernize the business and facilitates the restructuring of a business. In addition to these, it considerably helps to revive sick business units.

As a capital market intermediary the role of merchant banker extends to project counseling and funding, preparation of project reports, framing of capital structure, management of public issue through IPO and FPO, underwriting, loan syndication, due diligence, funds allocation from foreign institutional investors, mergers, amalgamation, acquisition, venture capital and restricting of debt and many more.

With increase in the initial and further public offering of companies listed under stock exchange, the role of the merchant bankers will find a significant place in the security market. The issuer company is entirely advised and guided on a right track by the investment manager right from issuance of prospectus for bringing a public offer, credit rating of the securities, listing those securities in a recognized stock exchange and monitoring the escrow account which is used for application fee and purpose of allotment of securities. Corporate experts are aware of the significance of prospectus which provides true information of the companies, its compliance structure and framework, their corporate strategies and policies, project funding, past dividend declaration, aspects of corporate governance and corporate social responsibility. The role of merchant banker in authenticating the Prospectus is an important task before a company brings any public issue and with due regard to the registration process of such prospectus before the Registrar of Companies, the opinion of the merchant banker as an independent professional is required.

\section{MERCHANT BANKER AND ITS WIDE FUNCTIONS IN CORPORATE FINANCE}

Fundamentally, every decisions taken by corporations has some financial implications and any decision which affects the finance of business is corporate finance. The financial decision which are taken by the Board and management have a direct impact on the entire business module and hence the role of investment bankers/ merchant bankers comes in play for financing a corporate.

Published By: 
The most important activity pertaining to any business organization is to arrange and locate for the pool of funds, as business are ordinarily subjected to risks and losses it is the merchant banker which helps to provide concrete framework by which issue company will be able to analyze how to boost the capital structure of the company. The merchant banker also functions to analyze the debt-equity ratio of company during assessing the capital needs of a company and gives opinion to the enterprises what type of financial securities should they issue so that they can easily meet the capital needs and further invest in a valuable project which will promote maximize the wealth of the entire stake-holders.

\section{HOW MERCHANT BANKER HELPS THE COMPANY TO RAISE FINANCE?}

Every certified merchant bankers under SEBI is required to act in consonance of the rules and regulations prescribed by the Security Exchange Board of India. Merchant Bankers monitors the security trading mechanism of the corporations on how it can raise its share capital, promote a brand image and smooth functioning of the activities to ensure healthy governance. Companies indulged in capital market should adhere the laws and regulations binding on them. Laws pertaining to security market are Companies act, 2013, Depositories act, 1996. SEBI Act, 1992 and its allied rules and regulations makes essential and binding for corporations to hold annual general meeting for discussion related to ordinary business and special business, except one person company. The agenda of annual general meeting includes the discussions concerning ordinary and special business. The the corporation will meet the expenses.

Let us understand by the help of a diagram, the various reasons why a corporation needs to raise funds:

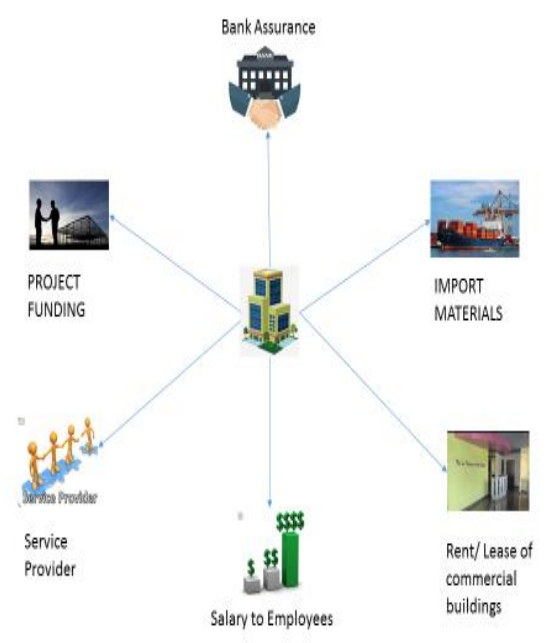

From the above illustration it is crystal clear that a corporation requires fund for multifarious purposes starting from paying salaries to its employees, cost of service providers, finance for project funding, syndicate finance, bank guarantee and many more, it is thus capital raising is a frequent discussion in board meetings and general meetings where the role of merchant banker is like an expert opinion to address how the corporation will arrange its finance. It is with the opinion of the investment managers/merchant bankers discussion involves the requirement of capital needs and how

that board passes its resolutions in the meeting whether and what extent public issue are to made so that the company can meet its requirement together with smooth functioning and effective governance. Merchant Bankers are said to perform the following functions in this regard which helps the board and the management of the company to run its activities smoothly:

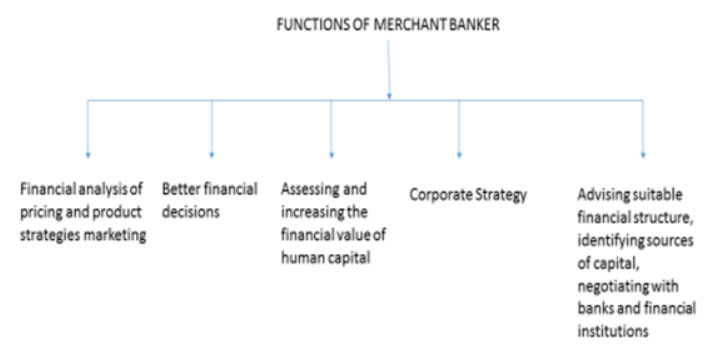

\section{SERVICES PROVIDED BY MERCHANT BANKERS}

- Promotional Activities

To increase the value of share-capital, to establish a concrete business module, to develop a strong compliance framework and to maximize the value of share-holders are the essential targets of all business dealing with corporate transactions. In this regard, merchant bankers assist the corporations in perceiving designs, identifying profitable projects, preparing probable reports and creating a brand image.

\section{- Portfolio Management}

Merchant bankers as a capital market intermediary assist the corporations in effective controlling and managing of securities. They assist the investors to make the investment decisions and also advise prior to any investment in securities any taxation or inflation related issues.

- Consultation with the Credit Rating Agencies

The diversified roles of merchant banker also extends to the consultation with the leading credit rating agencies in India. Top management of the company are always required to establish a concrete framework before opening a public issue through capital markets and in this regard the guidance of the merchant banker in consultation with credit rating agencies supports the company to maximize its capital and share-holders value. Higher credit rating implies higher premium and eventually higher issue price and in this sense companies with the services of merchant baker and credit rating agencies attract more investors in stock market. Stock-holders are always with the positive potential to earn profits and maximize its value and invest in such securities that yield high profits and returns despite knowing that shares issued at premium. Leading Credit rating agencies in India are CRISIL (Credit Rating Information and Services of India Limited), ICRA (Investment Information and Credit Rating

\section{Published By:}

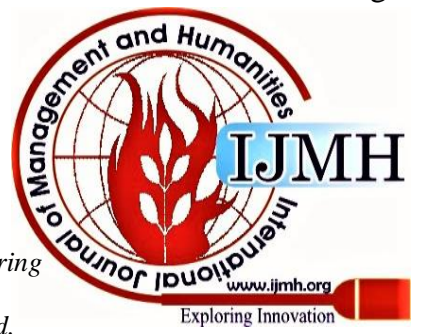


Exploring the Role of Merchant Banker as Capital Market Intermediary: With Special Reference to Role Played Under Stock Market

Agencies, CARE (Credit Analysis and Research Limited) etc. In 2017 CRISIL was awarded the best credit rating agencies at the capital market intermediary excellence awards 2016-17 by ASSOCHAM in consultation with SEBI.

- Role in Publicity and Advertisement

Merchant Banker is an expert to whom the responsibilities of overall public issue management is given or delegated by the companies. With a large requirement of funds for establishing a concrete business module, companies take the assistance of merchant bankers for pooling funds from public and financial institutions on varied terms and conditions of contractual agreements. Public issue management is one of key area of study where merchant bankers design it sources to manage funds. It is also important that listed companies under Stock exchange are required to register the prospectus before the concerned registrar of companies and SEBI prior to making an offer or invitation of securities to the public. Prospectus is a detailed document through which company invites subscriptions to or purchase of securities and are to be framed in such a manner that funds can be generated in a smooth and soothing manner. In the process of registration of prospectus prior to an initial public offer, the role of merchant banker extends as an expert opinion in authenticating the prospectus as keeping in mind public issue management is an important content. It also contain the details about the underwriter of the issue including all the relevant credentials and the amount underwritten by them. Here merchant banker services extends from registration of the document till listing of the shares. Services of merchant bankers provides publicity of such issue, providing underwriting support and handing the entire corporate strategy. Apart from these general activities, certain regulatory compliances including filing applications, taking approvals from government and financial institutions are also taken care by the merchant bankers.

- Dealings with Government undertakings

Leading merchant bankers in India like Goldman Sachs and Citi group has been selected by the government among the top rated merchant bankers to manage the portion of government stake sale in Indian Oil Corporation Ltd in 2017 as reported by sources. Apart from these, other bankers were nominated by the Department of investment and Public Asset Management for managing the issue are Deutsche Equities, SBI capital markets and ICICI securities. Sources reported that Indian oil corporation hopped to a net profit of Rupees 3720.62 crore on higher purifying margin and inventory gains. Another example where the Indian government has witnessed a surge through stake sale was NALCO and HUDCO, where an amount of Rupees 1200 crore was raised by means of initial public offering.

- Assisting Corporations to achieve the highest ethical standards

A corporation is always required to act in consonance with the changing laws and regulations. For effective corporate governance and its smooth functioning corporations are required to follow proper business ethics and standards which will eventually assist the company to leverage the intellectual capital, capital structure and relationships with other stake holders and organizations. Merchant bankers attempts to help the corporations in building strong relationships with the leading business organizations and also act as key player in maintenance of high ethical standards.

- Private Equity

As a capital market intermediary, merchant bankers provides end-to-end advisory and consulting services to the companies for raising funds through equity/quasi-equity from various investors and financial sources. As a private equity advisors, it helps the company to understand the company's requirement and shareholders targets. It helps in formulating optimum capital nurturing solutions for the clients to make them understand the value, quantum and time of investment. Thus helping in decision making to negotiate the best financial dealings with other business organizations at domestic and international level.

- Project Management

Project management is also one of the important services provided by the merchant bankers. The activities and services under project management ranges from instructing the clients about the site of the plan, formulating a project report, guiding practical studies and finding out the bases of funds for financing it.

- Corporate Restructuring

Restructuring of corporations are important part of business transactions. A corporate restructuring may result from merger or acquisition or amalgamation of remaining corporate units. However this corporate restricting demands the role of merchant bankers who can help in negotiations, due diligence of financial documents and other related legal formalities.

- Depository related services

Merchant banker also extends its services as depository participant registered under National Securities Depository Limited which holds stock, shares and other securities in dematerialized form in Indian Capital Market. Using innovative technology and platforms merchant bankers supports the investors and brokers to make dealings and transactions in capital market. As capital intermediaries are required to be registered under various authorities like NSDL and SEBI, this ensures and enhances reliance of the investors on the capital markets. Merchant bankers act as a tool which ensures protection and soundness of Indian market places by evolving settlement solutions that will endure to cherish the growth of financial services industry.

\section{- E-Depository services}

Internet based approach depository services are also now handled by the merchant bankers which lets Demat account holders and brokers submit delivery instructions online. One can also view the delivery status on the referred Speed-E website.

\section{- Quality Trusteeship Services}

Apart from other multifarious services, merchant bankers also offers services relating to Trusteeship, Security trusteeship, monitoring agencies and principally acts as a trustee to privately placed debt issuances, domestic borrowings and other cross border transactions.

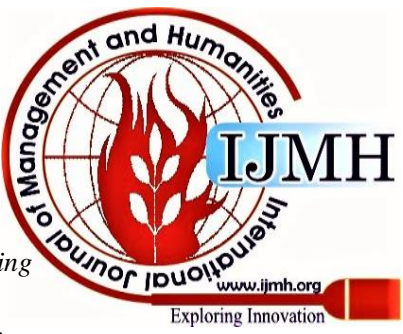




\section{- Services pertaining to Debt Solutions}

Merchant Bankers are leading consultants of solutions relating to debts in the form of bonds and debentures and loan syndicating. Merchant banks are very much acquainted with the handling debt issuances of mid and large size loans or bonds and organized loans to meet the specific necessities of the clients and projects.

- Role as a clearing bank for various exchanges registered under SEBI

Under the domain of capital market, several exchanges registered under SEBI operates and functions under the supervision of merchant bankers and beside managing the public issue investment managers at times acts as a "clearing bank" for the registered platforms under SEBI and deals with manifold capital market funding services. A live example is Axis Bank who activities extends to operate as clearing bank for NSE (National Stock Exchange),BSE (Bombay Stock Exchange), MCX ( Multi Commodity Exchange), Indian Commodity Exchange of India Ltd (ICEX) etc.

- Counselling clients prior to Merger and Acquisition

Merchant bankers through their professional skill and knowledge act as a contextual background in various landmark transactions both in domestic and international level. Their services is not exhaustive and extends to identify, maneuver and implement customized pioneering clarifications for the clients so that they can gain a familiarity of smooth merger and acquisition. In cases connected to M\&A transactions merchant banker suggests the corporations to develop board-room relationships with all corporates irrespective of the size and business module. It also provides the framework of deal structuring capabilities and closure experiences, knowledge based skills to improve extensive relationships with industries and regulatory bodies.

- Portfolio Management

It is always wise to have knowledge, experience and time before investing in capital market. Capital market is such a platform which requires sufficient knowledge and demand of time from the clients to play as an investor. Investors and clients vary from the perspective of financial capacity and size thus it ranges from individual to a Financial Institutional investors who invest in capital markets. Merchant Bankers thus assist as portfolio managers to high net worth individuals and big investors to maximize profit and the value of their shares by such investment.

\section{MERCHANT BANKER: HOW TO SELECT?}

Intermediaries operating inside the capital markets are required to be registered under the rules and regulations prescribed by SEBI. It is a mandate for the merchant bankers to get registered under SEBI before playing as a underwriter or consultant in corporate transactions. Thus a certificate for registration is an essential component for merchant banker before entering the field of security market. However choosing an organized merchant banker is a challenge for the corporations because corporations had to keep in mind what suits them the best in order to raise its capital fund and for smooth functioning of the organizations. Some strategies are to be implemented by the corporations before indulging a public issue manager as the fate of the business lies on their hands:

Track Record: Business dealers always keeps a record in order for the future compliances. Before selecting a merchant banker for public issue management, a due diligence should be made on the records of the merchant banker pertaining to its earlier dealings and managing IPO's.

Nature of dealings: In order to maximize the share-holders value a corporation requires funds and pertaining to locate the sources and to pool funds, corporations are expected to arrange a merchant banker. The selection of such intermediary would be such that it should be have a strong focus on the industry as well as who are highly acquainted with the market sentiments.

Research based skills: It is always good to do an extensive research before formulating any policy or entering any transactions. Due diligence is always expected to be made before entering in to a corporate transactions. Since there are different facets which are to be observed before opening a public issue through IPO, the selected merchant banker must possess the proficiency and aptitude of systematically investigating the vital information's on capital structuring, venture capital, and other important facets relating to public issue management.

Experience Skills: Merchant Bankers must be well versed with the ambience of capital markets, they should have possess the expert knowledge relating to underwriting issues, stock dealing and investment, monitoring the debt-equity ratio buying and selling of stocks .

\section{LAWS AND REGULATIONS PERTAINING TO MERCHANT BANKERS}

As we are all aware that capital market is entirely governed by Security Exchange Board of India. Merchant banker being a piece and parcel of the security market are also required to act in adherence to laws and regulation of security exchange. By virtue of section 30 of the SEBI Act, 1992 it has made rules for several constituents of capital market.

The SEBI (Merchant Bankers Regulations), 1992 contains some important provisions relating to registration of merchant bankers, adequate fees to be paid for such registration, certificate renewal, procedural aspect for investigation and inspection by SEBI, books of account and actions taken against merchant banker with due regard to cancellation or suspension of registration of merchant banker. However merchant bankers under security exchange board of India should strictly adhere to the capital adequacy norms. For category- I merchant bankers, the minimum net worth fixed by SEBI was one crore and later enhanced to five crore through the amendment of 1995.

\section{GUIDELINES PROVIDED UNDER SEBI (MERCHANT BANKERS) REGULATIONS, 1992}

Compliance is the pillar of success for all entrepreneurs who are engaged in business activities. With this hope and aspirations, SEBI strictly provided some guidelines for the operations of merchant bankers in capital market:

\section{Appointment of compliance officer mandatorily}

\section{Published By:}

Blue Eyes Intelligence Engineering

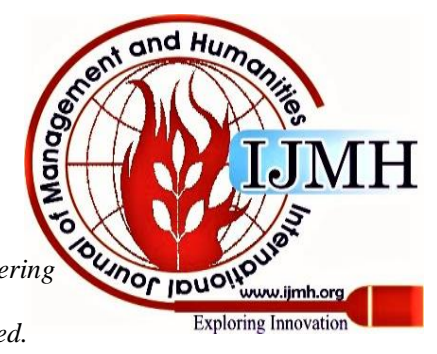


Exploring the Role of Merchant Banker as Capital Market Intermediary: With Special Reference to Role Played Under Stock Market

2. Inspection of records, books, documents etc. by officers appointed under SEBI.

3. Collection of renewal fees from merchant bankers by SEBI time to time.

4. SEBI also imposed underwriting obligation upon the merchant bankers to the range of five percent of the size of the issue or Rupees Twenty Five Lakhs whichever is lesser.

In addition to this a separate code of conduct is also prescribed for monitoring the merchant bankers. As professionals have to strictly abide by the rules and regulations framed from time to time, merchant bankers are also within the purview of the laws governing capital markets. A code of conduct thus ensures that merchant banker should act in conformity to the laws and regulation prescribed by the authority for protecting the interest of the entire stakeholders operating inside capital market, advising clients from time to time, intimating the Security exchange board of any legal proceedings that may be pending vice-versa, fully responsible to the issuer company, should be always available and accountable to the investors in regard to IPO and other public issue management matters, counselling and advising the issuer company and abide strictly by the rules and regulations framed by SEBI.

\section{TOP MERCHANT BANKERS IN INDIA AND WORLD WIDE}

India has near about six hundred merchant bankers. As per credit ratings top merchant bankers around the globe are Goldman Sachs, Credit Suisse and Morgan Stanley etc. A strong merchant banker always aims to offer expert guidance and tactful strategies on all related corporate transactions. In addition to this merchant bankers also contributes towards a due diligence prior to decide a public issue management. It is always beneficial for corporations to take the expert guidance and advices of the leading merchant bankers which ultimately helps the corporations to achieve the highest ethical standards and protection of client interest. In India among the toppers, Kotak Mahindra Bank occupies the first position in terms of handling initial public offer. As per the IPO rankings, Kotak investment banking is one of the leading investment bank providing multifarious services ranging from equity and debt capital market issuances, advises and guides merger and acquisition transactions, infrastructure activities and capital mobilization. Equity is also one of important component of capital issue and as per rankings of equity capital market, leading merchant banker was Goldman Sachs who dealt with the public issue on the back of Sun Pharmaceuticals. Goldman Sachs a leading merchant banker providing service around the globe records to accumulate Rupees 13,647 crore from 67 IPO's in 2015-16 . In India other leading merchant bankers like Axis Bank, ICICI Bank has also recorded about seven IPO's with leading corporations Alkem, Syngene, Teamlease, Quickheal etc.

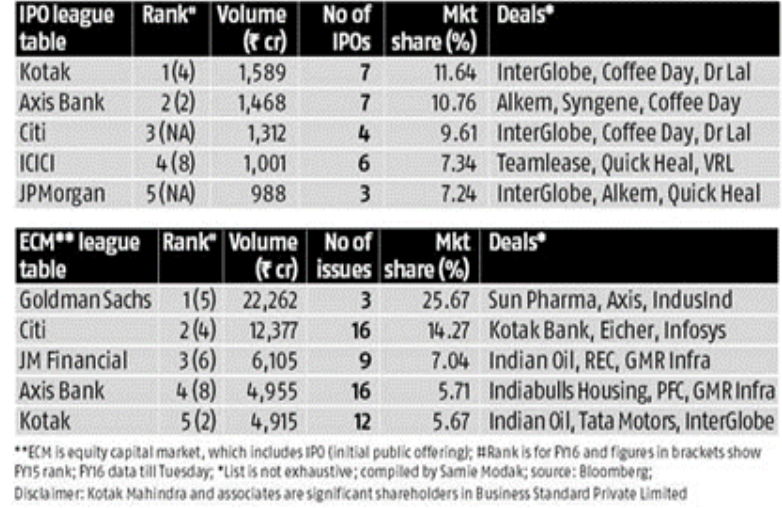

\section{RESULTS}

From the above research it can be crystal clear that a detailed guideline has been provided by SEBI rules and regulations pertaining to merchant bankers but still there are some gaps which are required to be confronted for addressing the recent challenges faced by merchant bankers under the security market. It is true that merchant bankers provides multi facets services in connection to capital markets but sometimes they are posed with serious challenges. One of the biggest challenges which are faced by the merchant bankers is in conducting due diligence prior to business transactions as most of the merchant banker services are connected to the banking aspects and as such they are not well equipped with all corporate transactions, thus committing violations of laws governing capital markets. For conducting due diligence, experts opinions are required before entering in to any big transactions so that proper evaluation and assessment of the records of target company can be done which will ultimately recommend whether the transaction will be profitable or not. It has been seen that many corporate transactions failed as due to lack of proper due diligence in the arena of legal, business and other compliances. Merchant bankers should always be aware prior to transactions related to distressed merger and acquisition and takeover services. It is for thus reason Security Exchange Board of India has imposed huge penalty on the merchant banker for violation of the rules pertaining to due diligence obligations under the Takeover regulations and merchant banker regulations. It has also been observed that SEBI has taken a stringent view on the duty and obligations of the merchant banker who are required to adhere strictly in regard to compliance management and assessment of the company and promoters independently, notwithstanding that whether the true records of the acquirer company are provided by the target corporation timely or not.

\section{CONCLUSION}

As per the guidelines of Security Exchange Board of India, the role of merchant banker as a capital market intermediary extends up to the activities pertaining to public issue management. However this merchant banker can perform multifarious manifold activities which are to be considered in the long run.

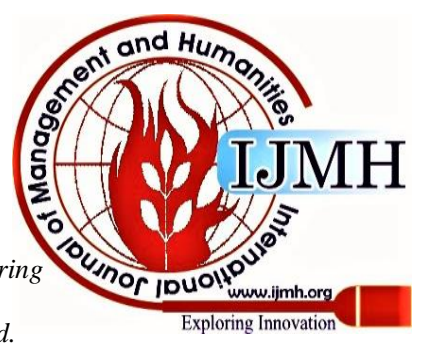


Their roles in the capital market have multidimensional facets and as such when they are guided by the stringent guidelines their activities are restricted and does not explore beyond public issue. Moreover the indulgence of capital adequacy norms in SEBI (Merchant Bankers) Regulations, 1992 imposes a bar on the young independent professionals from entering as capital market intermediary which ultimately creates a discrimination on the ground of capital adequacy despite possessing the capabilities to works as independent merchant banker.

However as an expert in public issue management it is not always wise for the company to impose full responsibility upon the merchant banker and if in any case any detrimental situation is apprehended to occur the issuer company is also required to act in collaboration with the appointed merchant banker for mitigating the risks and undertakings. It has been witnessed on several occasions that company making default in refunding of the excess application fee or the scheduled allotment application amount which ultimately creates a negative impression on the merchant banker as public would think that the issue manager is in default and not the ultimate company. The merchant bankers are required to conduct due diligence before the issuance of prospectus on behalf of any issuer company, as they are the independent expert to authenticate it. A company may propose to issue shares to the public at large but the flow of capital should be managed by the merchant bankers and hence before dealing with money of investors/public, they should always be aware while drafting, advertising and promoting the brand image of the company ensuring that prospectus is made in conformity with the laws and regulations and not detrimental in the interest of the public.

\section{REFERENCES}

1. Subhajit Chakraborty, Assistant Professor of Law, Adamas University, Kolkata.

2. https://www.lawctopus.com/academike/role-intermediaries-securitiesmarket/

3. https://www.nism.ac.in/certification/index.php/knowledge-base/finan cial-planning-2

4. https://businessjargons.com/merchant-banking.html

5. https://www.federalbank.co.in/merchant-banking\#undefined2

6. https://www.crisil.com/en/home/Executive-Training-Programmes/clas sroom/Programmes/company-valuation-concepts-and-techniques.htm

7. https://kalyan-city.blogspot.com/2011/10/what-is-merchant-bankingmeaning.html

8. https://www.axisbank.com/business-banking/capital-market-services

9. https://blog.ipleaders.in/merchant-banking-regulated-india/

10. https://ceohangout.com/role-of-a-merchant-banker/

11. https://blog.ipleaders.in/essential-role-merchant-bankers/

12. https://www.business-standard.com/article/markets/top-five-merchant -bankers-116032901365_1.html

13. https://www.business-standard.com/article/markets/top-five-merchant -bankers-116032901365_1.html

\section{AUTHORS PROFILE}

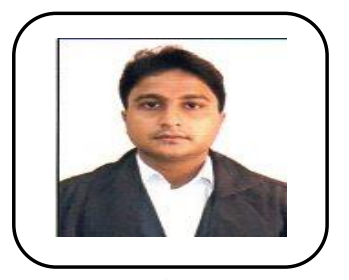

Mr. Subhajit Chakraborty, is currently engaged as an Assistant Professor of Law in Adamas University. $\mathrm{He}$ is currently pursuing Ph.d in the area of Corporate Law from Adamas University and has completed LL.M with Business Law Specialization from Indian Law School, Pune. After completing his undergraduate from University of Calcutta, Mr. Subhajit Chakraborty joined as a Legal Practitioner (Civil and Criminal) in various districts courts of West Bengal.
His areas of interest are Procedural Law, Corporate and Taxation Law, Business Law and Family Law.

Articles Published

1. Evidentiary Value of Accomplice in the Light of Procedural Laws in India published in Legal Service India online Legal Advice ISBN NO 978-81-928510-0-6.

2. FIR its evidentiary value, Consequences on denial by the Police to lodge ISBN NO 978-81-928510-0-6.

3. A critical analysis of Interim Budget, 2019 through the glasses of a Legal Apprentice ISBN NO 978-81-928510-0-6.

4. LLP: A hybrid composition of Company and Partnership firm published in International Journal of Law Volume 5; Issue 3; May 2019; Page No, 104-106, ISSN: 2455-2194.

5. Stalking in India: Too many cases, Too less convictions paper presented and published in Adamas University Law Journal.

6. Importance of Compliance Technology in Marketing Industries published in International Education and Research Journal- ISSN NO: 2454-9916

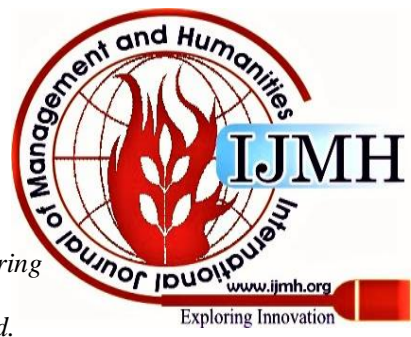

